\title{
浅海域における薄層覆砂の堆積特性 \\ SAND DEPOSITION CHARACTERISTICS OF THIN SAND CAPPING IN SHALLOW WATER
}

\author{
武田将英 1 - 山田良平 $2 \cdot$ 中澤慎一 2 -五明美智男 $3 \cdot$ 篠原邦彦 $4 \cdot$ 上野雅明 5 \\ Masahide TAKEDA, Ryohei YAMADA, Shin-ichi NAKAZAWA, Michio GOMYO, \\ Kunihiko SHINOHARA and Masaaki UENO
}

\author{
1正会員 東亜建設工業 (株) 技術研究開発センター († 230-0035 横浜市鶴見区安善町1-3) \\ 2東亜建設工業 (株) 千葉支店工事室 ( ₹ 260-0024 千葉市中央区中央港1- 12- 3) \\ 3フェロー 博(工) 東亜建設工業 (株) 技術研究開発センター († 230-0035 横浜市鶴見区安善町1-3) \\ 4国土交通省 関東地方整備局 千葉港湾事務所長（广 260-0024 千葉市中央区中央港1- 11- 2) \\ 5前＼cjkstart国土交通省 関東地方整備局 千葉港湾事務所副所長 ( 7260 - 0024 千葉市中央区中央港1-11- 2)
}

\begin{abstract}
There are terrible problems that the organic sediments on the sea bed destroy the ecosystem all around the closed water. Generally, the two improving methods for the bottom sediments which target such the organic sediments are executed. The one is a dredging method which removes them outside, and the other is a capping sand method which covers the sea bed with the sand. This paper describes the sand deposition characteristics of thin sand capping when the sand was dumped by either a backhoe or a grab bucket into shallow water, because the construction demands the sand piled up as thinly and uniformly as possible. They were clarified through the field research at our construction site. Finally, the average layer thicknesses were almost equal to the planned layer thicknesses in any case of the dumping either the dredged sand or the pit sand. The coefficient of variation of the layer thickness became larger as the planned layer thickness decreased. Thus in the thin sand capping, it found that we have to set more surcharge for the quantity of sands, because the error of layer thickness would grow.
\end{abstract}

Key Words : Sand capping, shallow water, backhoe, grab bucket, dredged sand, pit sand

1.はじめに

東京湾・大阪湾・伊勢湾など多くの閉鎖性内湾で は, 過去に堆積した有機污泥による底質環境の悪化 により，生物相が貧困化し，最悪の場合には湾全体 の生態系に悪影響を及ぼしていることが問題となっ ている.このような有機污泥を対象とした底質改善 策としては, 污泥を系外一除去する浚渫工法と污泥 を良質な砂で覆う覆砂工法が広く採用されている。 干山 ${ }^{1)}$ は，底質環境の改善ならびに経済性の観点か らみた理想的な覆砂工法の用件として，「必要最小 限の薄さで污泥を舞い上げることなく，短時間に広 くまくこと」と整理し，項目毎の必要覆砂厚を表- 1 に取りまとめた . 谷の上で, 環境改善効果の発現・ 維持のために必要と考えられる覆砂厚30cmに，施工 性への対応としての20cmを加えた $50 \mathrm{~cm}$ 程度が適正覆 砂厚の目安であると示した .

一方，干山の報告から10年以上経過した現在にお いては, 公共事業コス卜縮減や建設材料の省資源化 といった観点から，更なる薄層覆砂の実現が求めら
れるようになってきている．海域における土砂投入 に関する沈降・堆積特性に関する研究は, 古くは 1960年代の箭内 ${ }^{23)}$ から始まり，2000年以降も荒井

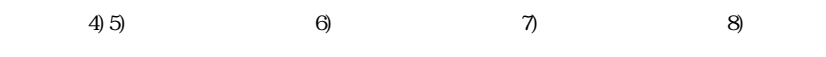
多くの研究者によって精力的に実施されてきている. しかし, これらの研究の多くは, 比較的水深の大き い場所における全開式もしくは底開式土運船での直 投を対象としており，浅海域の工事で一般的なバッ クホウやグラブによる投入を対象にしたものはない . 谷のため, 浅海域において薄層覆砂を施工する際は, 施工管理が可能な覆砂厚の設定と出来形の許容精度

表- 1 必要覆砂厚等の検討 ${ }^{1)}$

\begin{tabular}{c|l|r}
\hline 区 分 & \multicolumn{1}{|c|}{ 項 目 } & 必要厚等 \\
\hline \hline \multirow{4}{*}{ 環境改善効果 } & 溶出削減効果 & 30cm以上 \\
\cline { 2 - 3 } & 溶出削減効果 (持続性) & 30cmで20年 \\
& 50cmで30年 \\
\cline { 2 - 3 } & 底生生物相 & $10 \mathrm{~cm}$ 以上 \\
覆砂形状の維持 & 海域利用 (漁業の影響) & $10 \mathrm{~cm}$ 以上 \\
\multirow{2}{*}{ 施工性 } & 施工精度 & $\pm 10-20 \mathrm{~cm}$ \\
\cline { 2 - 3 } & めり込み厚 & $2-10 \mathrm{~cm}$ \\
\hline
\end{tabular}


などがいつも問題となる．乥こで，本研究では，覆 砂厚への主要な支配要因と考えられる投入材料，投 入方式，投入時の水面衝撃の有無，1投あたりの投 入時間を変えることにより，薄層覆砂施工における 堆積特性の把握を目的とした現地調査を実施した .

\section{2. 現地調査の概要}

\section{（1）覆砂工の概要}

現地調査の対象となった覆砂工は，国土交通省関 東地方整備局発注の「平成21年度東京湾浚渫土砂有 効活用試験工事」において実施された . 覆砂工の施 工場所は, 図-1に示す千葉県富津岬北側の水深4m 5m静穏な浅海域で, 図-2に示す覆砂工の総面積

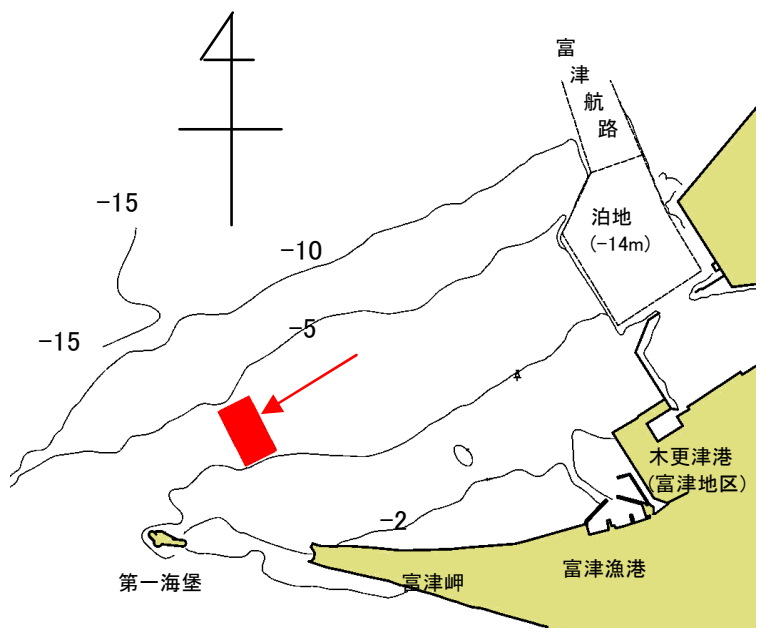

図-1 覆砂工位置図

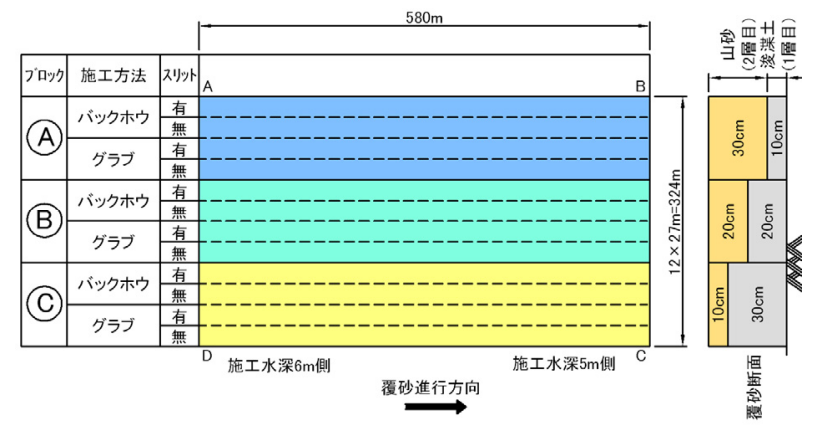

図-2 覆砂平面図及び断面図

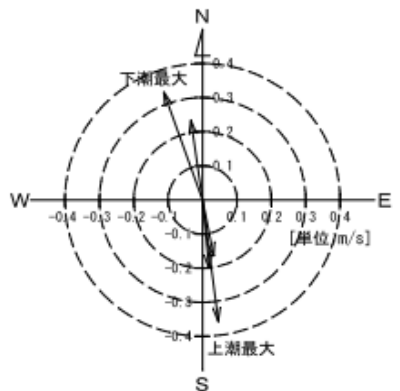

図-3 覆砂平面図及び断面図
は， 18.8万 m² (延長580mx 幅324m) であった，こ れを27n幅の施工レーン毎に，覆砂材料 (下層 : 浚 渫砂, 上層：山砂），施工機械 (バックホウ船，グ ラブ船)，投入方法，計画覆砂厚 $(10 \mathrm{~cm}, 20 \mathrm{~cm}$, $30 \mathrm{~cm})$ を変化させて覆砂工を実施した .

なお，施工海域での海底上2〜3mにおける流速は， 大潮期で最大 $0.35 \mathrm{~m} / \mathrm{s}$ ，小潮期で最大 $0.20 \mathrm{~m} / \mathrm{s}$ 程度で あった．例として，工事期間中の2010年6月29日に 測定した大潮期の流向流速图を図-3に示す．また， 覆砂工の施工期間中には, 関東地方に台風の接近は なく，外力による大幅な地形変化は見られなかった．

\section{（2）覆砂材料の諸元}

覆砂工に使用した浚渫砂，山砂の粒径加積曲線を 図-4に示す. 产れ光れの材料の土質試験結果の概要 は以下の通りである .

a) 浚渫砂

浚渫砂は, 富津市小久保地区から土取りしたもの を使用した . 中央粒径 $\mathrm{D}_{50}=0.12 \mathrm{~mm} \sim 0.15 \mathrm{~mm}$, 細粒分 含有率 $\mathrm{FC}=8.0 \sim 14.6 \%$, 土粒子の密度 $\rho_{s}=2.72 \sim$ 2. $74 \mathrm{~g} / \mathrm{m}^{3}$ とほぼ均質な細砂であった．図-5(a)に示 すように浚渫砂の含水状態は飽和であった．また， よく締まった砂であったため，浚渫砂投入時には， 土砂塊状で落下した。

b) 山砂

山砂は, 千葉県君津市の五行台産と吉野産を使用 した. 中央粒径 $\mathrm{D}_{50}=0.22 \sim 0.28 \mathrm{~mm}$, 細粒分含有率 $\mathrm{FC}=1.3 \sim 3.2 \%$ 、均等係数 $\mathrm{Uc}=1.88 \sim 2.52$, 土粒子の 密度 $\rho_{s}=2.72 \sim 2.74 \mathrm{~g} / \mathrm{m}^{3}$ と, 両者ともにほぼ均質な 細砂であった . 図-5(b)に示すように山砂の含水状 態は表乾状態であった . 乾いたゆるい砂であったた め，山砂投入時には粒子群として落下した .

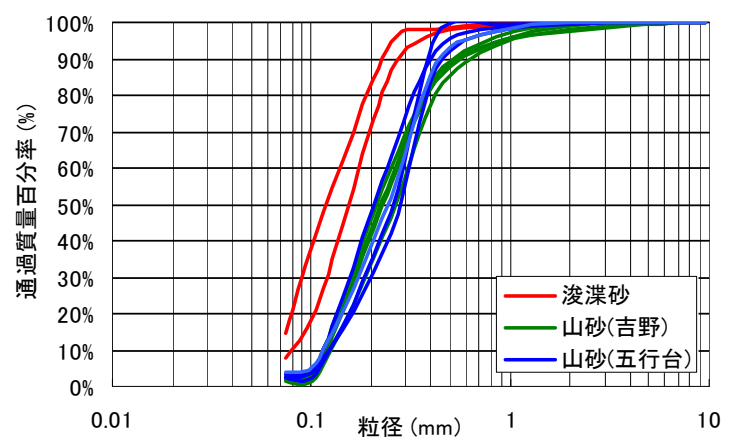

図-4 粒径加積曲線

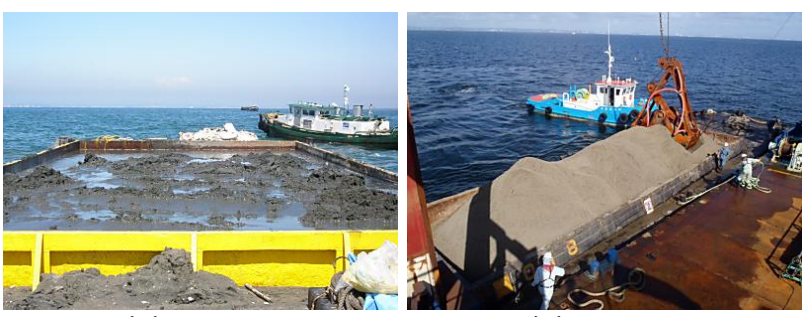

(a) 浚渫砂

(b) 山 砂

図-5 覆砂材料の含水状態 
（3）施工機械の諸元及び土砂投入方法

a) 施工機械の諸元

覆砂工には，図-6に示すバックホウ船（山積 2. $4 \mathrm{~m}^{3}$ ) とグラブ船 (山積 $5.5 \mathrm{~m}^{3}$ ) を使用し, 污濁防 止枠内へ土砂投入を行った . 污濁防止枠の寸法は, 内寸法13. $5 \mathrm{mx}$ 13. $5 \mathrm{~m}$, 膜の垂下長は2mであった .

b) 土砂の投入方法

土砂の投入方法は，図-7(a) に示す覆砂材を水面 から直接投入する方法 (直接投入) と, 覆砂材の水 面への衝突速度を抑制する目的で，污濁防止枠内に 図-7(b) に示すスリットを設置して投入する方法 (スリット投入) の2 種類を実施した . 図-7(b)に 示すように，湿潤な土砂をスリット投入する場合に は，スリット上に土砂が一旦堆積する．堆積した土 砂は, 污濁防止枠が動摇することにより生じた波に よって, 徐々に侵食されながら水中に落下する. 図-8に示すスリットは, 隙間間隔が10cmとなるよう 山型鋼を用いて製作されており，静水面よりやや高 い位置に設置することで適度な侵食が起こり，1〜 2 分程度で投入を終えることができた .

c) 土砂の投入回数

計画覆砂厚 $(10 \mathrm{~cm}, 20 \mathrm{~cm}, 30 \mathrm{~cm})$ に応じて一定量の 覆砂材料を投入できるよう, 表-1に示す回数の覆砂 材料をバケット山積みで投入した．投入回数を決定 するにあたり，覆砂材料の締まり具合を考慮して， 割増係数を浚渫砂1.1, 山砂1.3と設定した。なお, 覆砂材料の投入に当たっては，表-2に示す覆砂厚と 投入割付の例のように，できるだけ污濁防止枠内に 均等に投入できるよう配慮した .

d) 土砂の投入時間

バックホウ船では, ブーム操作により投入時間 (バケット内の土砂を投入し始めてから投入し終え るまでに要する時間) をオペレータが任意に変更で きる．乥こで，今回の覆砂工では，投入時間を $5 \mathrm{~s}$, $10 \mathrm{~s}, 20 \mathrm{~s} の 3$ 種類とした . また , グラブ船は, 投入 時間に変化を持たせず，バケットを一気に開放する だけのケースを実施した .

\section{（4）覆砂材料の堆積厚}

a) 污濁防止枠直下における堆積厚の確認

樣々な投入条件での堆積特性の把握を行うため， 污濁防止枠 1 個分への投入を実施した後に枠直下に 堆積した覆砂材料の堆積厚を確認した . 堆積厚の確 認は, 各施工レーンの施工水深5 $\mathrm{m} 及 ひ ゙ 6 \mathrm{~m}$ 位置で実 施した .ここで, 施工水深とは, 深浅図での水深に 平均潮位1mを加えた施工時の平均的な水深を指す. 今回の施工場所における底質は砂質土であったため， コア抜きによる堆積厚の確認ができなかった . 乥こ で, 覆砂材料の投入直後に, 標尺 (設置個数: 浚渫 砂施工時9-16個，山砂施工時9個) を海底に予め設 置し, 投入完了後に, 堆積した覆砂材の厚さを潜水 士により読み取った 。 (a) バックホウ船

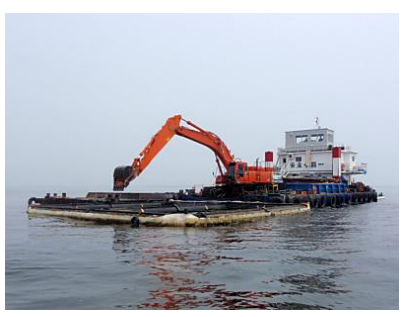

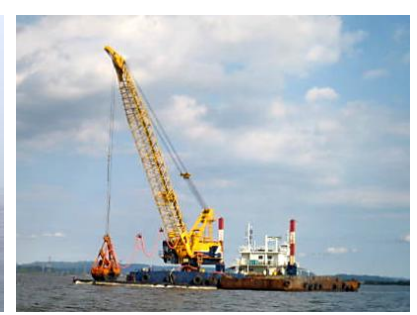

(b) グラブ船
図-6 施工機械

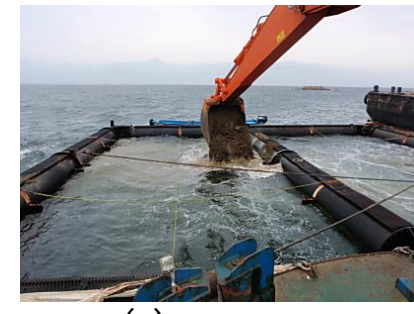

(a) 直接投入
図-7 施工機械

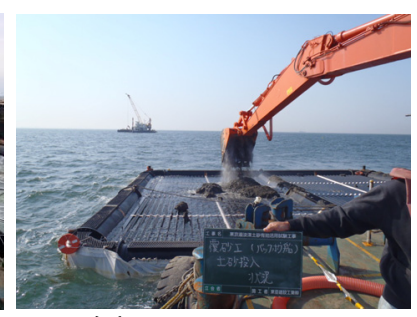

(b) スリット投入

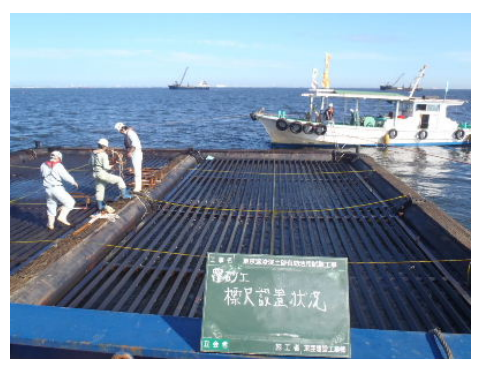

図-8 スリット

表- 1 污濁防止枠 1 個分への投入回数

\begin{tabular}{|c|c|c|c|c|}
\hline 覆砂材 & 割増係数 & 計画覆砂厚 & $\begin{array}{l}\text { バックホウ } \\
\text { ( 山積2. } 4 \mathrm{~m}^{3} \text { ) }\end{array}$ & $\begin{array}{c}\text { グラブ } \\
\left.\text { ( 山積5. } 5 \mathrm{~m}^{3}\right) \\
\end{array}$ \\
\hline \multirow{3}{*}{ 浚渫砂 } & \multirow{3}{*}{ 1. 1} & $30 \mathrm{~cm}$ & 25回 & 11回 \\
\hline & & $20 \mathrm{~cm}$ & 17回 & 7回 \\
\hline & & $10 \mathrm{~cm}$ & 8回 & 4回 \\
\hline \multirow{3}{*}{ 山砂 } & \multirow{3}{*}{ 1. 3} & $30 \mathrm{~cm}$ & 30回 & 13回 \\
\hline & & $20 \mathrm{~cm}$ & 20回 & 9回 \\
\hline & & $10 \mathrm{~cm}$ & 10回 & 4回 \\
\hline
\end{tabular}

表- 2 覆砂厚と投入割付の例 (バックホウ船・浚渫砂)

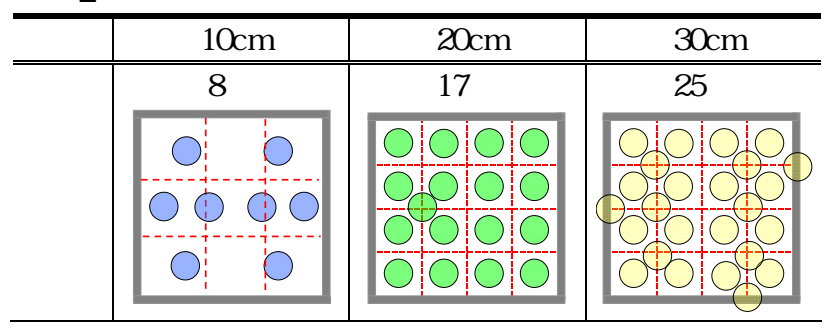

b) 深浅測量結果による覆砂厚の確認

本工事における出来形確認は, 音響測深機 (PDR1300型，1素子) を用いた深浅測量により行った。 深浅測量では. 覆砂材料の拡散の影響を考慮して, 施工範囲の周囲を50m外側に拡張した延長680mx 幅 430mの範囲を測量した。また，深浅測量の測線は， 
延長・幅共に10n間隔であつたため，27n幅の各施工 レーンにおける覆砂厚の確認には, 深浅測量結果を 兴のまま用いることができなかった．乥こで，図-9 に示すような各施工レーンを 2 分割する污濁防止枠 の中央線上 (図中の桃色矢印) での值となるよう線 形補間を実施した．乥して，覆砂工実施の事前事後 の差をとって覆砂厚の確認を行なった .

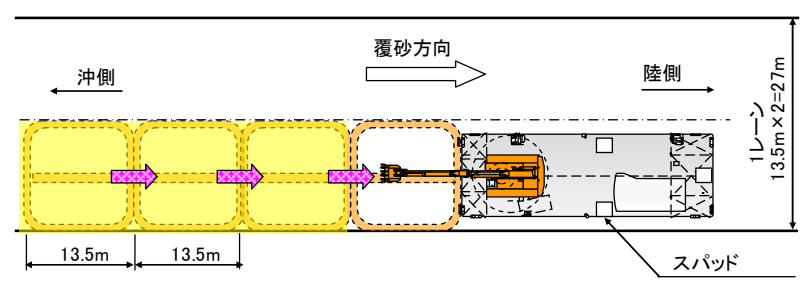

図-9 施エレーンと污濁防止枠の関係

\section{3. 現地調査結果}

（1）含水状態が異なる覆砂材料の堆積特性

a) 直接投入の場合

計画覆砂厚30 $\mathrm{cm}$ における直接投入の平均堆積厚と その変動係数 (標準偏差を平均堆積厚で割ったもの で相対的なばらつきを表す) を弚れ光れ図-10, 図11に示す . 図中の水平軸における $\ulcorner\mathrm{BH}(5 \mathrm{~s})\lrcorner$ は投入 時間5sでのバックホウ船による投入であることを指 す . バックホウに着目すると, 湿潤状態の浚渫砂で は，投入時間が長いほど，污濁防止枠内に堆積しや すく, かつ変動係数が小さくなる (相対的にばらつ きが小さくなる) 傾向が見られた .一方，表乾状態 の山砂では，投入時間の長短に関わらず, 平均堆積 厚及び変動係数はほぼ同じ值を示した, 次に, グラ ブに着目すると, 平均堆積厚・変動係数共に, 投入 時間の短いBH( 5s) と似たような傾向であった .

覆砂材料の違いによって, 平均堆積厚の傾向に差 が見られたのは, 次のような状況であったと推察さ れる . 湿潤な浚渫砂の場合は, バケットから放出さ れる土砂は, 土砂塊となって水面に衝突する . 兴の ため，投入時間が短いケースでは，寸法の大きな土 砂塊が運動量をある程度保持したまま海底に衝突し て，周囲に散ったと考えられる，一方，表乾状態の 山砂の場合には, 砂粒子が, 気泡を巻き込みながら 個々に水面に衝突する，关のため，砂粒子の運動量 が大幅に消失し，ゆっくりと水中を落下したと考え られる。

b) スリット投入の場合

計画覆砂厚30cmにおけるスリット投入の平均堆積 厚と关の変動係数を弚れ光れ図-12, 図-13に示す. バックホウやグラブに関係なく，いずれのケースで もほぼ一定の平均堆積厚となった . 山砂の場合は， 直接投入とスリット投入に大きな差は見られなかっ た .これは表乾状態の土砂投入の場合には, 土砂が
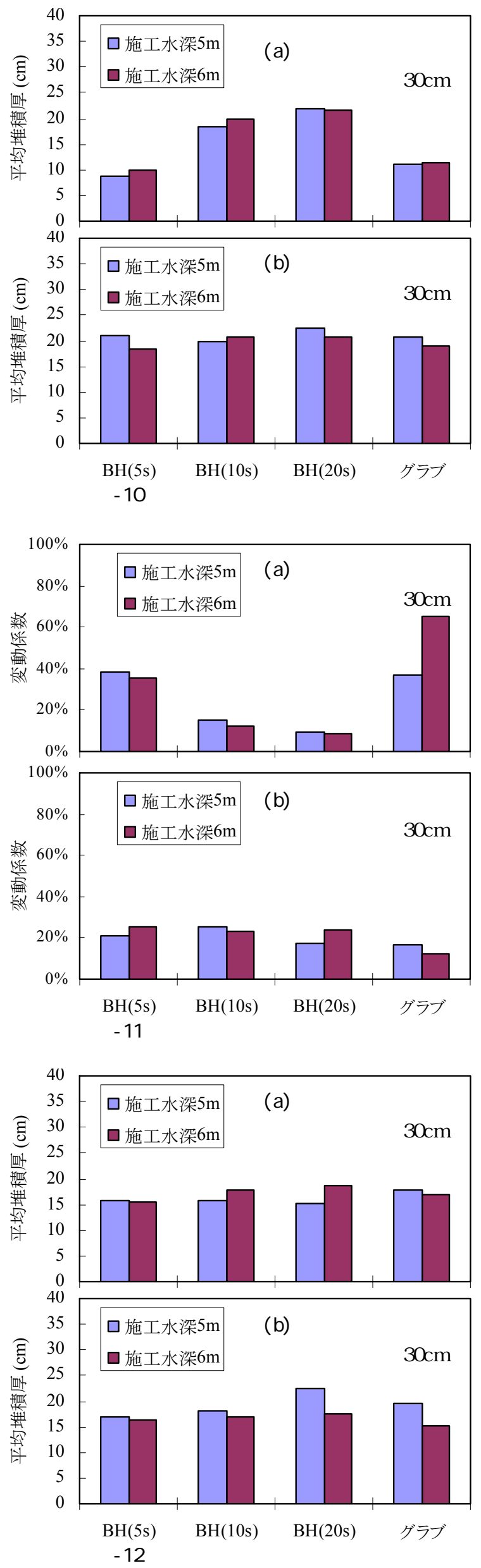


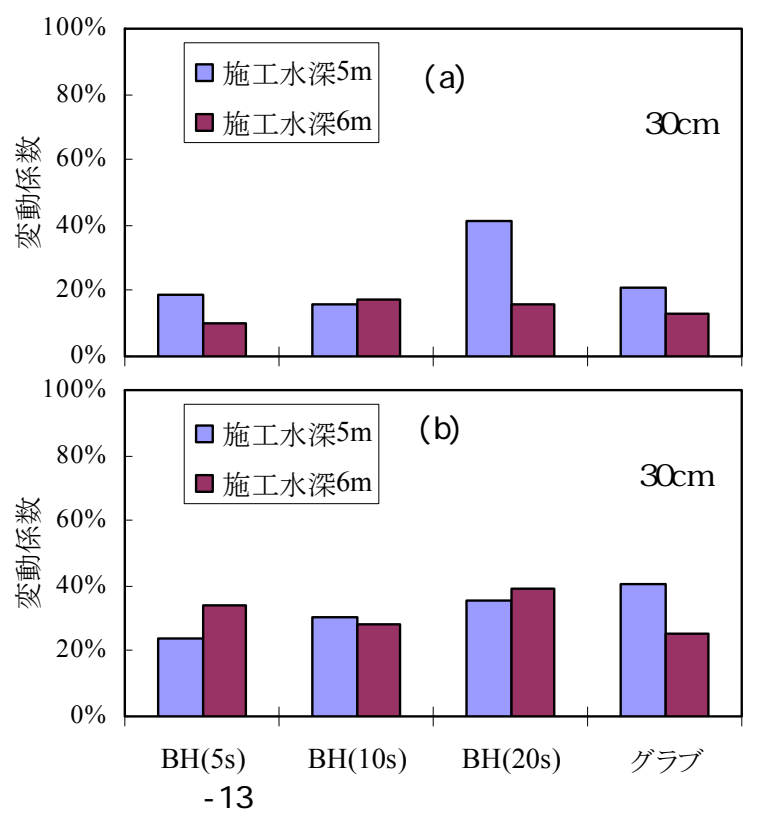

スリット上に堆積することなく直接水中に落下する ため, スリット設置が堆積厚等に与える影響が極め て少なかったことによると考えられる，一方，湿潤 な浚渫砂の場合には, スリット上に土砂が一旦堆積 することにより，土砂の水中への落下形態がいずれ のケースでもほぼ同じようになったと考えられる . 弚のため, 湿潤な浚渫砂を投入する際は, 適切な隙 間間隔のスリットを用いることで，サイクルタイム を落とすことなく，均質に土砂を堆積することがで きることが分かった .

\section{（2）計画覆砂厚が異なる場合の堆積特性}

計画覆砂厚が $10 \mathrm{~cm}, 20 \mathrm{~cm}, 30 \mathrm{~cm}$ ときの湿潤な゙浚 渫砂におけるバックホウ船での直接投入 , グラブ船 での直接投入，グラブ船でのスリット投入を図-14, 図-15, 図-16に示す .この図から，グラブ船の直接 投入では，堆積厚に傾向がなく，ばらつきが大きい ことが分かる . また , バックホウの直接投入やグラ ブ船のスリット投入では, 計画覆砂厚が薄くなるに 従って，バラつきが大きくなることが分かった .な お，表乾状態の山砂の直接投入でも，バックホウ船， グラブ船ともに計画覆砂厚が薄くなるに従って，バ ラつきが大きくなった .

\section{（3）薄層覆砂の施工精度}

最終出来形を, 覆砂材料と覆砂厚毎に整理した結 果を表-3に示す. 最終的に, 浚渫砂・山砂ともに, 平均覆砂厚は計画覆砂厚に近い值を得ることができ た .しかし, 計画覆砂厚が小さくなるほど, 平均覆 砂厚の変動係数が大きくなる傾向か湿著に見られた． このことから，薄層覆砂では出来形にばらつきが大 きくなることが分かった .

覆砂工事における一般的な出来形管理では, 計画 覆砂厚より小さい(薄い) ことを許容しない場合が

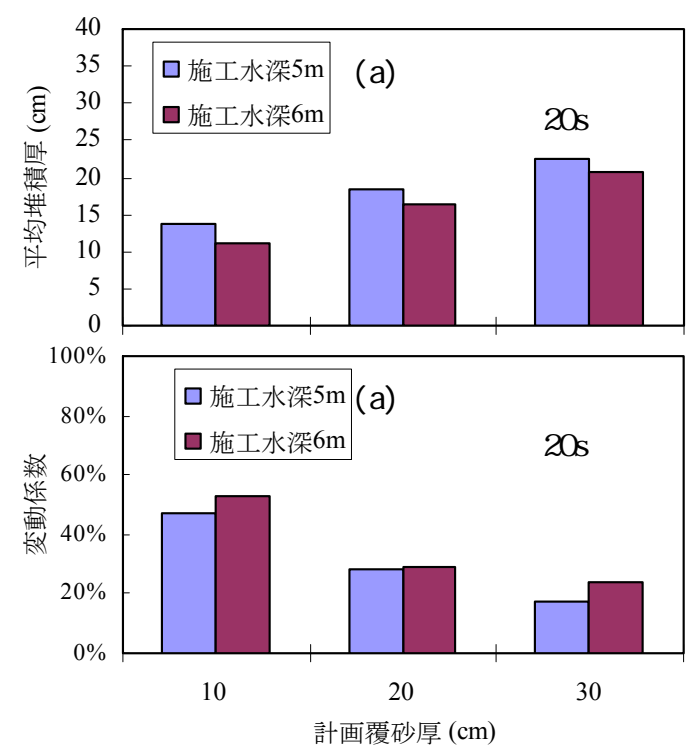

図-14 バックホウの直接投入における堆積特性

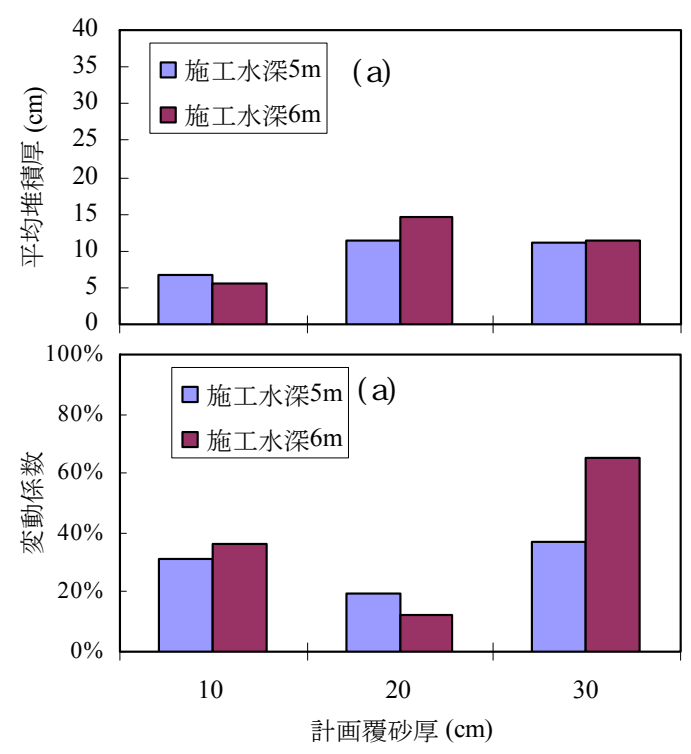

図-15 グラブ船の直接投入における堆積特性
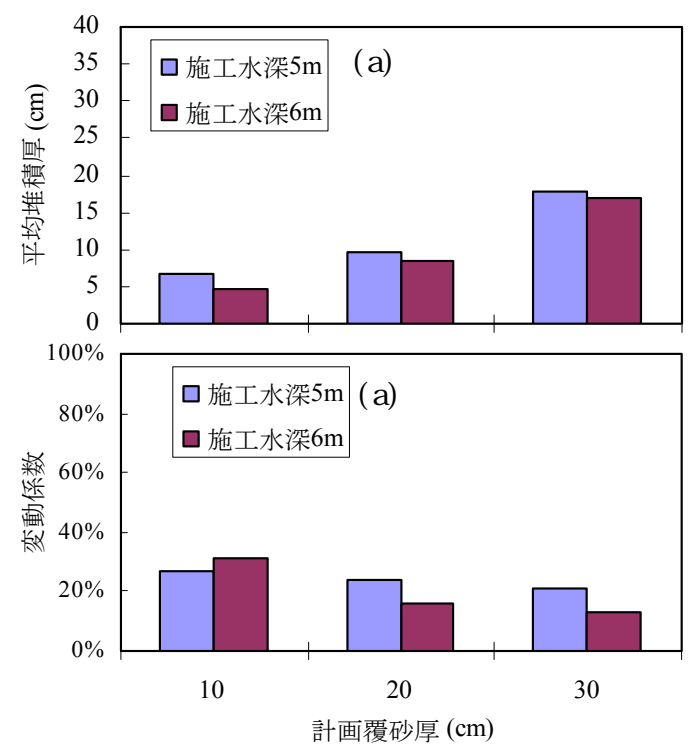

図-16 グラブ船のスリット投入における堆積特性 
多い, 弚のため, 薄層覆砂の場合には, 覆砂材の割 増係数を多く設定する必要があることが示唆された . 弚こで，表-3に示す結果から，計画覆砂厚と割増し すべき覆砂厚の関係を示したものを図-17, 図-18に 示す.ここでは, 覆砂厚分布は, 図-19に示す正規 分布に従うものとし, 2 次関数の近似曲線を描いた。 例えば，図-17の場合は，計画覆砂厚を $\mu-3 \sigma=10 \mathrm{~cm}$ にした場合，割増しを考慮した覆砂厚は $t=30 \mathrm{~cm}$ と なり, 同じく $\mu-3 \sigma=20 \mathrm{~cm}$ した場合には $t \fallingdotseq 40 \mathrm{~cm}$, 同じく $\mu-3 \sigma=30 \mathrm{~cm}$ にした場合には $t \fallingdotseq 50 \mathrm{~cm}$ という結 果を得る. 弚の結果，割増率は光れ光れ3.0，2.0， 1.7となり，薄層覆砂の場合には覆砂材の割増係数 を多く設定する必要があることか理解できる .

\section{4.おわりに}

本研究で得られた成果は以下の通りである.

バックホウによる直接投入では, 湿潤状態にある 浚渫砂は, 投入時間が長いほど, 投入直下に堆積し やすく，ばらつきも小さくなる傾向が見られた . 一 方, 表乾状態の山砂では, 投入時間の長短に関わら ず，堆積厚及び変動係数はほぼ同じであった 。

計画覆砂厚が薄くなるほど, 堆積厚の変動係数が 大きくなる傾向か顕著に見られ，薄層覆砂では出来 形のばらつきが大きくなることが分かった . また , 覆砂工事での出来形管理では, 計画覆砂厚より薄い ことを許容しない場合が多く，薄層覆砂の場合には， 覆砂材料の割増を多く設定する必要があることが分 かった．なお，投入回数を変化させずに 1 回当たり の投入量を減じるなどの工夫をした場合には，変動 係数は多少抑制できると予想されるが, アーム長の 短い小型の機械を使用すると，土運船からの揚土が 困難になる等の施工上の課題がある .

\section{参考文献}

1) 干山善幸 : 沿岸の環境圏 , フジ・テクノシステム , pp. 1147- 1158, 1998.

2) 箭内寛治 : 砂および磁の水中落下の散らばりに関する 研究 - 静水中における場合 - , 土木学会論文集 , 第69 号, pp. 51- $57,1960$.

3) 箭内寛治 : 砂の集団投下および波を受けるときの平面 的な散らばりについて, 土木学会論文集, 第71号, pp. 28 - $34,1960$.

4) 荒井清, 矢内栄二, 五明美智男, 坂井彰, 阪井田茂, 松見吉晴: 底開式バージによる投入土砂堆積形状に関 する予測モデルの現地適用性について, 海岸工学論文 集 , 第47巻, pp. 986-990，2000.

5) 荒井清, 門田充史, 宗田修, 出口一郎: 誘起流速を考 慮した直投土砂堆積形状予測係数設定方法に関する研 究, 海岸工学論文集, 第50巻, pp. 836-839, 2003.

6) 重松孝昌, 錦織陽一, 廣瀬真由, 小田一紀 : 水中沈降 粒子群の三次元分散挙動に関するパラメトリック解析， 海岸工学論文集，第48集 , pp. 1031- 1035，2001.

7) 矢内栄治, 松見吉晴, 伊東剛, 住谷圭一: 土運船によ る土砂投入堆積形状に関する簡易予測図表の提案, 海 岸工学論文集, 第52巻, pp. 861- 865, 2005.
8) 原田英治, 青木伸一, 後藤仁志, 細田尚 : 水中投入粒 子群挙動および誘起流動過程, 海岸工学論文集, 第53 巻, pp. 861- $865,2006$.

表- 3 覆砂工の最終出来形

\begin{tabular}{c|c|c|c|c}
\hline \multirow{2}{*}{ 覆砂材料 } & $\begin{array}{c}\text { 計 画 } \\
\text { 覆砂厚 }\end{array}$ & $\begin{array}{c}\text { 平 均 } \\
\text { 覆砂厚 } \\
\mu\end{array}$ & $\begin{array}{c}\text { 標準偏差 } \\
\sigma\end{array}$ & $\begin{array}{c}\text { 変動係数 } \\
V\end{array}$ \\
\hline \hline \multirow{3}{*}{ 浚渫砂 } & $30 \mathrm{~cm}$ & $27.3 \mathrm{~cm}$ & $5.7 \mathrm{~cm}$ & $21 \%$ \\
\cline { 2 - 5 } & $20 \mathrm{~cm}$ & $19.6 \mathrm{~cm}$ & $5.2 \mathrm{~cm}$ & $26 \%$ \\
\cline { 2 - 5 } & $10 \mathrm{~cm}$ & $12.3 \mathrm{~cm}$ & $3.9 \mathrm{~cm}$ & $39 \%$ \\
\hline \multirow{3}{*}{ 山 砂 } & $30 \mathrm{~cm}$ & $29.7 \mathrm{~cm}$ & $6.1 \mathrm{~cm}$ & $21 \%$ \\
\cline { 2 - 5 } & $20 \mathrm{~cm}$ & $20.6 \mathrm{~cm}$ & $5.5 \mathrm{~cm}$ & $27 \%$ \\
\cline { 2 - 5 } & $10 \mathrm{~cm}$ & $9.1 \mathrm{~cm}$ & $3.8 \mathrm{~cm}$ & $44 \%$ \\
\hline
\end{tabular}

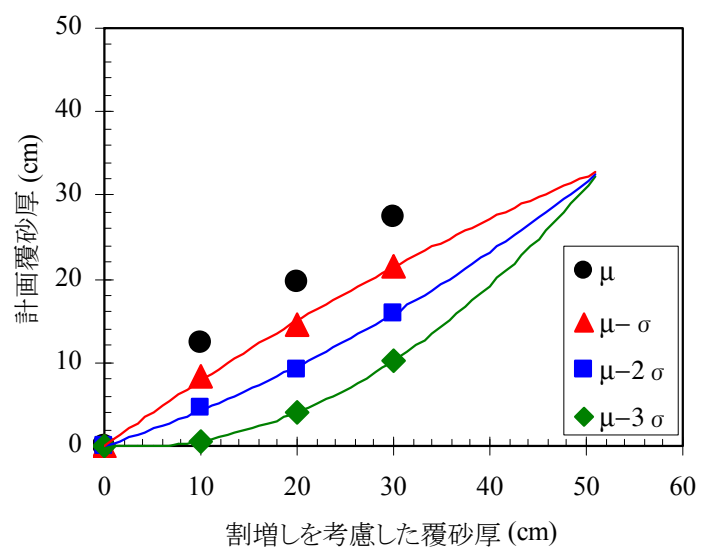

図-17 割増しを考慮した覆砂厚と計画覆砂厚 (浚渫砂)

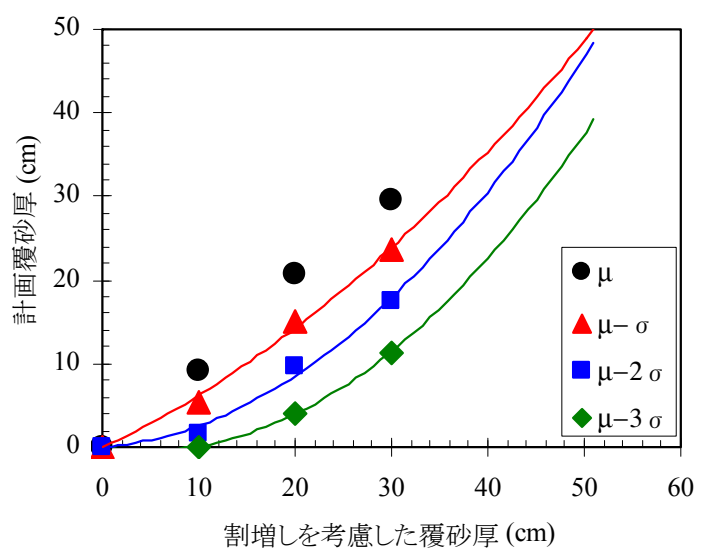

図-18 割増しを考慮した覆砂厚と計画覆砂厚 (山砂)

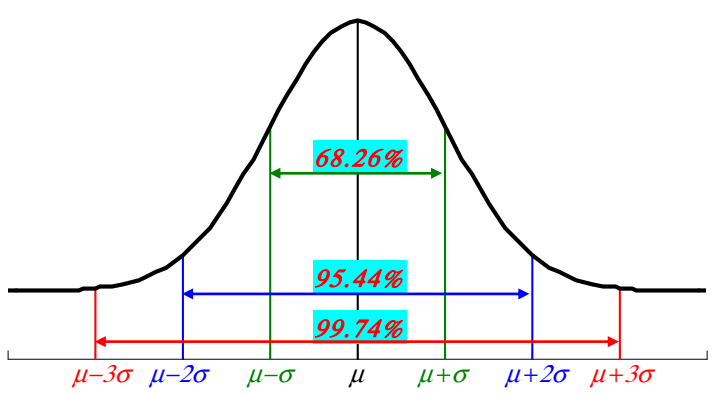

図-19 正規分布 